\title{
Nitrincola lacisaponensis gen. nov., sp. nov., a novel alkaliphilic bacterium isolated from an alkaline, saline lake
}

\author{
Pedro A. Dimitriu, ${ }^{1}+$ Sanjay K. Shukla, ${ }^{2}$ Jennifer Conradt, ${ }^{2}$ \\ M. Carmen Márquez, ${ }^{3}$ Antonio Ventosa, ${ }^{3}$ Anne Maglia, ${ }^{1}$ Brent M. Peyton, ${ }^{4}$ \\ Holly C. Pinkart ${ }^{5}$ and Melanie R. Mormile ${ }^{1}$ \\ ${ }^{1}$ Department of Biological Sciences, University of Missouri-Rolla, Rolla, MO 65401, USA \\ ${ }^{2}$ Marshfield Clinic Research Foundation, 1000 N. Oak Avenue, Marshfield, WI 54449, USA \\ ${ }^{3}$ Department of Microbiology and Parasitology, University of Sevilla, 41012 Sevilla, Spain \\ ${ }^{4}$ Department of Chemical Engineering, Washington State University, Pullman, WA 99164, USA \\ ${ }^{5}$ Department of Biological Sciences, Central Washington University, Ellensburg, WA 98926, \\ USA
}

Correspondence Melanie R. Mormile mmormile@umr.edu

\begin{abstract}
A novel alkaliphilic bacterium, strain $4 \mathrm{CA}^{\top}$, was isolated from decomposing wood taken from the shore of Soap Lake, a saline, alkaline lake in Grant County, WA, USA. Cells of the isolate were Gram-negative, asporogenous, short, motile rods that utilized only a limited range of organic acids as sole carbon and energy sources. In addition to oxygen, the strain possessed the ability to reduce $\mathrm{NO}_{2}^{-}$in the presence of acetate. Strain $4 \mathrm{CA}^{\top}$ was oxidase- and catalase-positive; it degraded Tween 60 , but not DNA, urea, gelatin or starch. It grew at $\mathrm{pH}$ values from $7 \cdot 5$ to $11 \cdot 0$, with optimum growth occurring at $\mathrm{pH} 9 \cdot 0$, and growth was observed in $\mathrm{NaCl}$ concentrations of $0 \cdot 2-1 \cdot 3 \mathrm{M}$, with optimum growth at $0.8 \mathrm{M} \mathrm{NaCl}$. The optimum temperature for growth was $37^{\circ} \mathrm{C}$. Strain $4 \mathrm{CA}^{\top}$ was resistant to erythromycin, bacitracin, novobiocin, polymyxin $\mathrm{B}$, neomycin, gentamicin, streptomycin, carbenicillin, rifampicin and tetracycline, and was susceptible to nalidixic acid, chloramphenicol, ampicillin and penicillin. The isolate's $16 \mathrm{~S}$ rRNA gene sequence indicated that it belonged to the $\gamma$-Proteobacteria, showing $90-94 \%$ similarity to its closest relatives. Maximum-likelihood phylogenetic inferences placed strain $4 \mathrm{CA}^{\top}$ within a novel lineage related to the marine bacterial genera Neptunomonas and Marinobacterium. The DNA G+C content of the isolate was $47 \cdot 4 \mathrm{~mol} \%$. On the basis of genotypic and phenotypic characterization, it was concluded that strain $4 \mathrm{CA}^{\top}$ should be placed in a separate taxon as a novel genus and species, with the proposed name Nitrincola lacisaponensis gen. nov., sp. nov. The type strain is $4 \mathrm{CA}^{\top}$ $\left(=\right.$ ATCC BAA $-920^{\top}=$ DSM $\left.16316^{\top}\right)$.
\end{abstract}

Soda lakes are highly alkaline, naturally occurring environments that harbour a microbiota representing most major prokaryotic lineages (Zavarzin et al., 1999). In particular, the majority of Gram-negative isolates and culture-independent bacterial clones retrieved from soda lakes belong to the $\gamma$ Proteobacteria (Jones et al., 1994, 1998; Ma et al., 2004),

Published online ahead of print on 3 June 2005 as DOI 10.1099/ ijs.0.63647-0.

tPresent address: Department of Forest Sciences, University of British Columbia, Vancouver, BC, Canada V6T 1 Z4.

Abbreviations: CA, coumaric acid; TEM, transmission electron microscopy.

The GenBank/EMBL/DDBJ accession number for the $16 \mathrm{~S}$ rRNA gene sequence of Nitrincola lacisaponensis $4 \mathrm{CA}^{\top}$ is AY567473. including strains related closely to typical aquatic bacteria such as Aeromonas and Pseudomonas (Duckworth et al., 1996), moderate halophiles from the Halomonas/Deleya group, and marine bacteria, e.g. Marinobacter (Rees et al., 2004).

Of the phylogenetically diverse Gram-negative, marine and/ or halophilic aerobes and facultative anaerobes, the genus Oceanospirillum is the most widely studied and has traditionally consisted of various types of bacteria that occur in marine ecosystems (Hylemon et al., 1973). DNA-rRNA hybridization experiments (Pot et al., 1989, 1992) and fatty acid analysis (Sakane \& Yokota, 1994) have revealed much intrageneric diversity within this group. Recently, analyses based on $16 \mathrm{~S}$ rRNA and $g y r B$ genes helped to clarify the taxonomic affiliation of the oceanospirilla and related 
bacteria (Satomi et al., 2002), leading to the redefinition of this genus to include four species. Other, less-studied genera affiliated with Oceanospirillum include Marinobacterium and Neptunomonas. These marine bacteria display the capability to grow on a wide range of substrates, including some polycyclic aromatic hydrocarbons in the case of Neptunomonas, and are frequently isolated from creosotecontaminated marine environments (González et al., 1997; Hedlund et al., 1999; González \& Whitman, 2002).

In this study, we report the isolation and characterization of a new bacterium, designated strain $4 \mathrm{CA}^{\mathrm{T}}$, obtained from Soap Lake, a meromictic lake with high alkalinity. Through the analysis of molecular and physiological properties, isolate $4 \mathrm{CA}^{\mathrm{T}}$ was found to bear resemblance to the Marinobacterium-Neptunomonas-Oceanospirillum cluster, although it was distinct enough to be separated into a novel genus.

Isolate $4 \mathrm{CA}^{\mathrm{T}}$ was obtained from decayed, red-coloured wood collected on the shore of Soap Lake, a meromictic, alkaline, saline lake located in Grant County, WA, USA. Soap Lake is a closed, evaporative system with neither a significant surface inlet nor outlet. This results in the concentration of salts, mainly sodium carbonate and sodium sulfate (Anderson, 1958). The current $\mathrm{pH}$ of the lake is about $9 \cdot 8$ and its $\mathrm{NaCl}$ concentration can exceed $10 \%(\mathrm{w} / \mathrm{v})$ (Walker, 1974). Two sections of wood (approx. $1 \mathrm{~cm}^{2}$ ) were removed aseptically from the sample and added to Soap Lake basal medium (SLBM), an enrichment medium for putative moderately halophilic, alkaliphilic bacteria. SLBM contained the following $\left(1^{-1}\right): \mathrm{CaSO}_{4}, 4 \cdot 0 \mathrm{mg} ; \mathrm{FeSO}_{4}$, $1.0 \mathrm{mg} ; \mathrm{NaCl}, 17.5 \mathrm{~g} ; \mathrm{SiO}_{2}, 5.0 \mathrm{mg} ; \mathrm{MgCl}_{2}, 4.0 \mathrm{mg}$; $\mathrm{MnSO}_{4}, 4.0 \mathrm{mg} ; \mathrm{NH}_{4} \mathrm{NO}_{3}, 50.0 \mathrm{mg} ; \mathrm{Na}_{2} \mathrm{SO}_{4}, 13.5 \mathrm{~g}$; $\mathrm{KH}_{2} \mathrm{PO}_{4}, 3 \cdot 0 \mathrm{~g} ; \mathrm{K}_{2} \mathrm{HPO}_{4}, 3 \cdot 0 \mathrm{~g} ; \mathrm{Na}_{2} \mathrm{CO}_{3}, 1 \cdot 0 \mathrm{~g}$; and $1 \mathrm{ml}$ trace element stock solution $\left[\mathrm{g} \mathrm{l}^{-1}\right.$ : sodium nitriloacetate, $1 \cdot 5 ; \mathrm{MgSO}_{4} \cdot 7 \mathrm{H}_{2} \mathrm{O}, 3 \cdot 0 ; \mathrm{MnSO}_{4} \cdot \mathrm{H}_{2} \mathrm{O}, 0 \cdot 5 ; \mathrm{NaCl}, 1 \cdot 0$; $\mathrm{FeSO}_{4} .7 \mathrm{H}_{2} \mathrm{O}, 0 \cdot 1 ; \mathrm{CaCl}_{2} .2 \mathrm{H}_{2} \mathrm{O}, 0 \cdot 1 ; \mathrm{CoCl}_{2} .6 \mathrm{H}_{2} \mathrm{O}, 0 \cdot 1$; $\mathrm{ZnCl}_{2}, 0 \cdot 13 ; \mathrm{CuSO}_{4} .5 \mathrm{H}_{2} \mathrm{O}, 0 \cdot 01 ; \operatorname{AlK}\left(\mathrm{SO}_{4}\right)_{2} .12 \mathrm{H}_{2} \mathrm{O}, 0 \cdot 01$; $\mathrm{H}_{3} \mathrm{BO}_{3}, 0 \cdot 01 ; \mathrm{Na}_{2} \mathrm{MoO}_{4} \cdot 2 \mathrm{H}_{2} \mathrm{O}, 0 \cdot 025 ; \mathrm{NiCl}_{2} \cdot 6 \mathrm{H}_{2} \mathrm{O}, 0 \cdot 024$; $\left.\mathrm{Na}_{2} \mathrm{WO}_{4} \cdot 2 \mathrm{H}_{2} \mathrm{O}, 0 \cdot 025\right]$. To enrich for bacteria capable of utilizing lignin-hydrolysis compounds, coumaric acid (CA) was added to a final concentration of $0.05 \%(\mathrm{w} / \mathrm{v})$. The final $\mathrm{pH}$ of the medium was adjusted to $9 \cdot 8$ with $1 \mathrm{M} \mathrm{NaOH}$. Cultures were placed in a shaking incubator (200 r.p.m.) at $37^{\circ} \mathrm{C}$. To obtain pure cultures, the enriched cells were streaked onto solid SLBM containing $0.05 \%(\mathrm{w} / \mathrm{v})$ CA ( $\mathrm{pH} 9 \cdot 8)$. The strain selected for further study was maintained on solid SLBM or nutrient agar (Difco) slants.

The carbon-source utilization pattern was ascertained with a salt basal medium (SBM) described previously (Mormile et al., 1999), except that the $\mathrm{NaCl}$, yeast extract and $\mathrm{NaNO}_{3}$ concentrations were lowered to $17 \cdot 5,0 \cdot 1$ and $0 \mathrm{~g} \mathrm{l}^{-1}$, respectively, and the $\mathrm{pH}$ was adjusted to $9 \cdot 0$. Each carbon source tested was added separately from sterile stocks to give a $1 \%$ final concentration, except for vanillic acid and CA, which were added at a concentration of $0.05 \%$. A growth test was considered positive when the $\mathrm{OD}_{600}$ reached or exceeded a value of 0.3 after $72 \mathrm{~h}$ at $37^{\circ} \mathrm{C}$. SBM containing acetate was used to determine growth responses to $\mathrm{pH}$ by adjusting, for each test, the $\mathrm{pH}$ at values ranging from 6.0 to 13.0 by using a finely adjusted $\mathrm{KH}_{2} \mathrm{PO}_{4} / \mathrm{K}_{2} \mathrm{HPO}_{4}$ or $\mathrm{Na}_{2} \mathrm{CO}_{3} / \mathrm{NaHCO}_{3}$ buffer system. The growth response to $\mathrm{NaCl}$ was measured by varying the $\mathrm{NaCl}$ concentration from 0 to $3.5 \mathrm{M}$. To determine whether the isolate required $\mathrm{Na}^{+}$ or $\mathrm{Cl}^{-}$, medium was prepared separately with $\mathrm{KCl}, \mathrm{Na}_{2} \mathrm{SO}_{4}$, $\mathrm{NaNO}_{3}$ or $\mathrm{Na}_{2} \mathrm{CO}_{3}$ to substitute for these ions. Tolerance to salt and $\mathrm{pH}$ values was determined by measuring $\mathrm{OD}_{600}$ after $48 \mathrm{~h}$ incubation at $37^{\circ} \mathrm{C}$. Tolerance to temperature was determined after growth in SBM with acetate for $48 \mathrm{~h}$. Potential electron acceptors other than oxygen were tested on SBM/acetate containing $0.001 \mathrm{~g}$ resazurin $\mathrm{l}^{-1}$ and included $\mathrm{NaNO}_{3}, \mathrm{NaNO}_{2}, \mathrm{Na}_{2} \mathrm{SO}_{4}, \mathrm{Na}_{2} \mathrm{SO}_{3}$ and $\mathrm{Na}_{2} \mathrm{SeO}_{4}$, each supplied at a concentration of $10 \mathrm{mM}$. Anaerobic conditions were achieved as described by Cutter et al. (1998).

Gram reaction was determined with a Gram-stain kit (Difco). Catalase and oxidase activities, as well as endospore production, were determined as described by Smibert \& Krieg (1994). Analyses for hydrolysis of starch and DNA were performed with starch agar (Difco) and DNase (Difco) media, respectively. The ability to reduce nitrate under aerobic conditions was assessed on nitrate broth (Difco) by following the manufacturer's recommendations. King's media $\mathrm{A}$ and $\mathrm{B}$ were used to determine the production of pigments (King et al., 1954). Additional enzymic activities were assayed by using API 20E strips (bioMérieux). Antibiotic susceptibilities were determined by using antibiotic discs (Becton Dickinson) on SBM at $\mathrm{pH} 9 \cdot 0$.

For transmission electron microscopy (TEM), a bacterial cell pellet obtained from an overnight culture was fixed with $2 \%$ glutaraldehyde $/ 2 \%$ paraformaldehyde in $0.1 \mathrm{M}$ cacodylate buffer. After the samples were washed several times, $2 \%$ liquid agar was added and, upon solidification, $1 \mathrm{~mm}^{3}$ portions were post-fixed in $1 \% \mathrm{OsO}_{4}$. En bloc staining was done in $1 \%$ aqueous uranyl acetate. Samples were dehydrated in an ethanol series and infiltrated with EponAraldite epoxy resin. The material was then placed into fresh resin in BEEM embedding capsules and polymerized at $60{ }^{\circ} \mathrm{C}$. After polymerization, blocks were sectioned on a Leica UCT ultramicrotome and ultrathin sections $(70 \mathrm{~nm}$ thick) were stained with $1 \%$ uranyl acetate and lead citrate. Samples were viewed and photographed in a JEOL 1200EX transmission electron microscope and imaged on Kodak 4489 TEM film. To visualize flagella, a $5 \mu \mathrm{l}$ aliquot of strain $4 \mathrm{CA}^{\mathrm{T}}$ culture was placed on a Ni sample disc and evaporated to dryness. The sample was placed in a $27 \%$ solution of phosphotungstic acid for $30 \mathrm{~s}$ and rinsed with ultrapure water before TEM.

To determine the DNA base composition, DNA was extracted and purified by the method of Marmur (1961) and its $\mathrm{G}+\mathrm{C}$ content was determined from the mid-point value $\left(T_{\mathrm{m}}\right)$ of the thermal-denaturation profile (Marmur \& Doty, 1962) by using the equation of Owen \& Hill (1979). 
The $16 \mathrm{~S}$ rRNA gene of strain $4 \mathrm{CA}^{\mathrm{T}}$ was PCR-amplified with the broad-range bacterial primers 27F (5'-AGAGTTTGATCCTGGCTCAG-3'), 806R (5'-GGACTACCAGGGTATCTAAT-3'), 13B (5'-AGGCCCGGGAACGTATTCAC-3') and 1527R (5'-AAGGAGGTGATCCAGCC-3') (Relman et al., 1992; Weisburg et al., 1991). PCR and sequencing reactions were performed by following the protocol described by Shukla et al. (2001). The sequencing reactions were resolved in an ABI 3100 gene analyser (Applied Biosystems). The assembled and edited 16S rRNA gene sequence of strain $4 \mathrm{CA}^{\mathrm{T}}$ was aligned with $16 \mathrm{~S} \mathrm{rDNA}$ sequences of closely related strains by conducting BLAST searches of GenBank and performing multiple alignments using CLUSTAL W (Thompson et al., 1994) with additional manual alignment. The phylogenetic relationships of each taxon were inferred by maximum-likelihood, parsimony and evolutionary-distance methods of phylogenetic reconstruction, using PAUP ${ }^{\star} 4.0$ b10 (Swofford, 2003). Maximumlikelihood trees were inferred by using the default starting parameters (neighbour-joining using a Jukes-Cantor model of evolution). Statistical support of the branch points was tested by performing 1000 maximum-likelihood bootstrap replications. Parsimony trees were inferred by conducting heuristic searches with the tree-bisection-reconnection branch-swapping algorithm, all positions were weighted equally and gaps were treated as missing. Pairwise distances were used to generate neighbour-joining/UPGMA trees using Hasegawa, Kishino and Yano (HGK85) distance.

When grown for 2 days at $37^{\circ} \mathrm{C}$ on solid SBM containing acetate, colonies of strain $4 \mathrm{CA}^{\mathrm{T}}$ were typically white, circular and convex, with entire margins and a diameter of 1-2 mm. Colonies of the culture grown on nutrient agar $(\mathrm{pH} 9 \cdot 8$ and $1.75 \% \mathrm{NaCl}$ ) exhibited similar morphology, but diameters were 3-4 $\mathrm{mm}$. Liquid nutrient broth also supported growth of strain $4 \mathrm{CA}^{\mathrm{T}}$, although the bacteria had a slight tendency to clump as cultures aged. Cells were motile, short rods that possessed a single polar flagellum and stained Gramnegative; they were typically $1.3-1.6 \mu \mathrm{m}$ long and $0.5 \mu \mathrm{m}$ wide. Electron microscopy analyses confirmed the Gramnegative structure (Fig. 1) and position and number of the flagella (Fig. 2). In most cases, strain $4 \mathrm{CA}^{\mathrm{T}}$ appeared as single cells. No endospore production was observed.

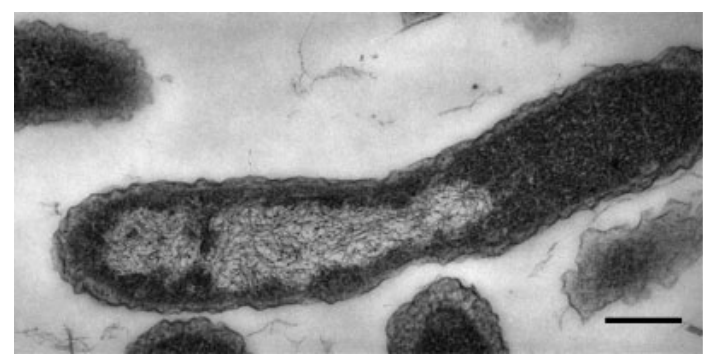

Fig. 1. Transmission electron micrograph of a thin section of cells of Nitrincola lacisaponensis $4 \mathrm{CA}^{\top}$. Bar, $0.2 \mu \mathrm{m}$.

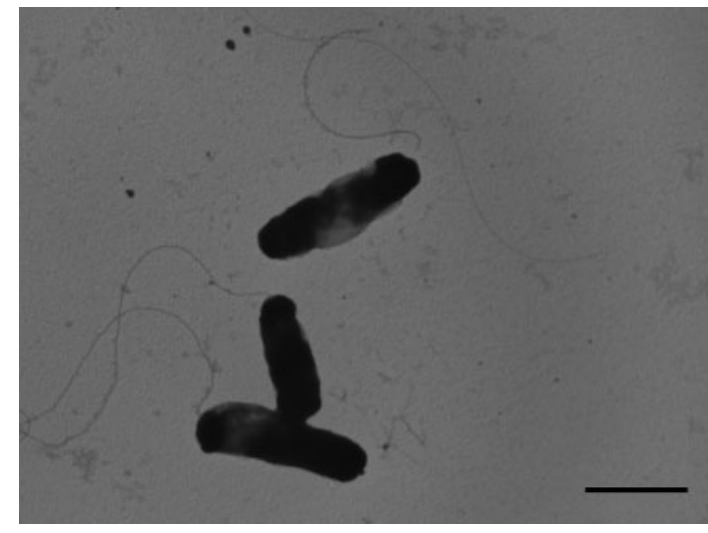

Fig. 2. Transmission electron micrograph of cells of Nitrincola lacisaponensis $4 \mathrm{CA}^{\top}$, showing a single, polar flagellum. Bar, $1 \mu \mathrm{m}$.

Strain $4 \mathrm{CA}^{\mathrm{T}}$ grew well in both liquid nutrient broth and solid nutrient agar with $\mathrm{pH}$ values ranging from $8 \cdot 0$ to $10 \cdot 0$. It could grow at $\mathrm{NaCl}$ concentrations of $0 \cdot 2-1 \cdot 3 \mathrm{M}$, with optimum growth occurring at $0.8 \mathrm{M} \mathrm{NaCl}$. It could also grow at $\mathrm{Na}_{2} \mathrm{SO}_{4}$ concentrations of $0 \cdot 2-1 \cdot 0 \mathrm{M}, \mathrm{NaNO}_{3}$ concentrations of $0 \cdot 2-1 \cdot 0 \mathrm{M}$ and $\mathrm{Na}_{2} \mathrm{CO}_{3}$ concentrations of $0 \cdot 2-1 \cdot 2 \mathrm{M}$. When $\mathrm{NaCl}$ and other sources of $\mathrm{Na}^{+}$were removed from the medium and replaced with $\mathrm{KCl}$, isolate $4 \mathrm{CA}^{\mathrm{T}}$ did not grow, indicating that it has a requirement for $\mathrm{Na}^{+}$. It grew best at $30-37^{\circ} \mathrm{C}$ and some growth was detected at $22{ }^{\circ} \mathrm{C}$, but it failed to grow at $4{ }^{\circ} \mathrm{C}$. When tested on finely buffered SBM, strain $4 \mathrm{CA}^{\mathrm{T}}$ had the ability to grow between $\mathrm{pH}$ values of $7 \cdot 5$ and $11 \cdot 0$, with optimal growth observed at $\mathrm{pH} 9 \cdot 0$. The final $\mathrm{pH}$ values measured in the media initially poised at $9 \cdot 0,9 \cdot 5,10 \cdot 0,10 \cdot 5$ and $11 \cdot 0$ were $9 \cdot 08,9 \cdot 57,9 \cdot 95$, $10 \cdot 44$ and $10 \cdot 92$, respectively. Hence, isolate $4 \mathrm{CA}^{\mathrm{T}}$ could be considered a strict alkaliphile (Horikoshi, 1998; Ivey et al., 1998).

The new strain was oxidase- and catalase-positive and did not exhibit lysine decarboxylase, ornithine decarboxylase or arginine dihydrolase activities. Strain $4 \mathrm{CA}^{\mathrm{T}}$ was negative for the production of $\mathrm{H}_{2} \mathrm{~S}$, Voges-Proskauer reaction and indole production; urea, gelatin, DNA and starch were not hydrolysed. Cells did not produce visible or fluorescent pigments when incubated on solid King's media B or A, respectively, two characteristics widely used for preliminary determination of pseudomonad species (Stanier et al., 1966; Palleroni, 1984). Strain $4 \mathrm{CA}^{\mathrm{T}}$ grew with $\mathrm{O}_{2}$ or $\mathrm{NO}_{2}^{-}$as electron acceptors in the presence of acetate, but not with $\mathrm{NO}_{3}^{-}, \mathrm{SO}_{4}^{2-}, \mathrm{SO}_{3}^{2-}$ or $\mathrm{SeO}_{4}^{2-}$. Under aerobic conditions, it utilized DL-lactate, acetate, pyruvate, malate, fumarate, succinate and Tween 60 . Additional characteristics are provided in the species description.

The $\mathrm{G}+\mathrm{C}$ content of the DNA of strain $4 \mathrm{CA}^{\mathrm{T}}$ was $47 \cdot 4 \mathrm{~mol} \%$, as determined by the thermal-denaturation method. The sequence of an approximately $1400 \mathrm{bp}$ portion of the 16S rRNA gene was obtained for isolate $4 \mathrm{CA}^{\mathrm{T}}$. No 


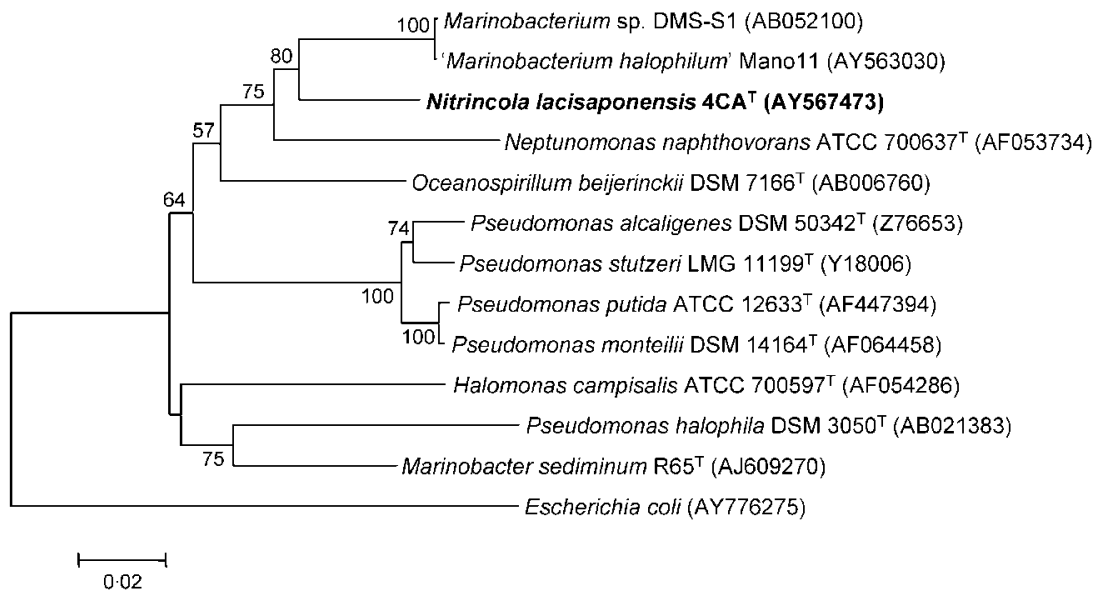

Fig. 3. Phylogenetic tree based on nearly complete 16S rRNA gene sequences of strain $4 \mathrm{CA}^{\top}$ and its relatives in the $\gamma$ Proteobacteria. Escherichia coli was used to root the tree. The significance of each branch is indicated by a bootstrap value calculated for 1000 subsets; values of $50 \%$ or greater are shown. Bar, 2 nucleotide substitutions per $100 \mathrm{nt}$.

sequences available in the public databases exhibited $>94 \%$ similarity to the sequence of strain $4 \mathrm{CA}^{\mathrm{T}}$. Phylogenetic analysis revealed that isolate $4 \mathrm{CA}^{\mathrm{T}}$ clustered within the $\gamma$-subclass of the Proteobacteria, encompassing the genera Neptunomonas, Marinobacterium and Oceanospirillum (Fig. 3). Some pseudomonads belonging to the Pseudomonas fluorescens intrageneric cluster, one of the two major clusters that comprise the genus Pseudomonas sensu stricto (Moore et al., 1996), formed a distinct subclade detached from strain $4 \mathrm{CA}^{\mathrm{T}}$. Maximum-likelihood, parsimony and distance methods resulted in highly similar tree topologies. Strain $4 \mathrm{CA}^{\mathrm{T}}$ had a mean of $90-91.8 \%$ sequence similarity to all taxa that fell into this cluster, and displayed $94,92.5$ and $93 \%$ similarity to the marine bacteria Marinobacterium sp. strain DMS-S1 (Fuse et al., 2000), Neptunomonas naphthovorans (Hedlund et al., 1999) and Oceanospirillum beijerinckii (Hylemon et al., 1973), respectively.

The phenotypic characteristics that differentiate strain $4 \mathrm{CA}^{\mathrm{T}}$ from closely related taxa are presented in Table 1. The strain could be distinguished from members of the genus Oceanospirillum by its shape and its ability to grow in the absence of $\mathrm{NaCl}$. Some phenotypic properties delineating strain $4 \mathrm{CA}^{\mathrm{T}}$ were also in marked disagreement with those that characterize members of the genus Marinobacterium: the type species, Marinobacterium georgiense, can utilize sugars and amino acids, requires a salt-based medium for growth and grows best at $\mathrm{pH} 7 \cdot 0$ (González et al., 1997; González \& Whitman, 2002). A similar physiological profile is observed for members of the genus Neptunomonas (Hedlund et al., 1999). None of the related genera can use $\mathrm{NO}_{2}^{-}$as an electron acceptor, nor do they exhibit an alkaliphilic phenotype.

The results presented here provide phenotypic and molecular (Fig. 3) evidence that warrants the affiliation of strain $4 \mathrm{CA}^{\mathrm{T}}$ to a separate, novel lineage, excluding it from any of the previously described genera of the $\gamma$-Proteobacteria to which it is phylogenetically related. Thus, we conclude that isolate $4 \mathrm{CA}^{\mathrm{T}}$ represents a novel genus and species, for which the name Nitrincola lacisaponensis gen. nov., sp. nov. is proposed.

\section{Description of Nitrincola gen. nov.}

Nitrincola (Nit.rin' co.la. L. neut. n. nitrum soda; L. masc. n. incola inhabitant, dweller; N.L. masc. n. Nitrincola an inhabitant of a soda environment).

Table 1. Phenotypic characteristics that differentiate strain $4 \mathrm{CA}^{\top}$ from phylogenetically related taxa

Taxa: 1, Nitrincola lacisaponensis $4 \mathrm{CA}^{\mathrm{T}}$ (this study); 2, Oceanospirillum; 3, Pseudomonas mosselli CFML 90-83 ${ }^{\mathrm{T}}$ (Dabboussi et al., 2002); 4, Neptunomonas; 5, Marinobacterium. ND, No data; +, positive reaction; -, negative reaction. Data were taken from González \& Whitman (2002) unless otherwise noted.

\begin{tabular}{|c|c|c|c|c|c|}
\hline Characteristic & 1 & 2 & 3 & 4 & 5 \\
\hline Cell morphology & Rods & Helical & Rods & Rods & Rods \\
\hline Optimum pH & $9 \cdot 0$ & ND & ND & ND & $7 \cdot 5$ \\
\hline $\begin{array}{l}\text { Optimum growth temperature } \\
\left({ }^{\circ} \mathrm{C}\right)\end{array}$ & 37 & $30-32$ & 30 & 30 & 37 \\
\hline Urease & - & - & ND & - & + \\
\hline Arginine dihydrolase & - & ND & + & - & ND \\
\hline Gelatinase & - & + & + & - & - \\
\hline Pigment production & - & ND & + & ND & ND \\
\hline DNA G + C content $(\mathrm{mol} \%)$ & $47 \cdot 4$ & $47-49$ & 63 & 46 & 55 \\
\hline \multicolumn{6}{|l|}{ Utilization of: } \\
\hline Galactose & - & - & - & + & ND \\
\hline Glucose & - & - & + & + & + \\
\hline D-Mannose & - & - & + & - & + \\
\hline D-Fructose & - & - & + & + & + \\
\hline DL-Lactate & + & + & + & ND & ND \\
\hline Malate & + & + & + & - & ND \\
\hline Ethanol & - & + & $\mathrm{ND}$ & ND & + \\
\hline Glycerol & - & - & + & + & - \\
\hline Propanol & - & + & ND & ND & + \\
\hline
\end{tabular}


Alkaliphilic, halotolerant and heterotrophic. Cells are non-pigmented, asporogenous, motile, Gram-negative rods. $\mathrm{NO}_{2}^{-}$and $\mathrm{O}_{2}$ can be used as electron acceptors. Fermentable carbon sources do not support growth. Chemoorganotrophic. Requires sodium for growth. Oxidase- and catalase-positive. Optimal $\mathrm{pH}$ for growth is $9 \cdot 0$. The genus is a member of the $\gamma$-subclass of the Proteobacteria. Isolated from a saline, alkaline lake. The DNA G $+\mathrm{C}$ content is $47 \cdot 4 \mathrm{~mol} \%\left(T_{\mathrm{m}}\right)$. The type species is Nitrincola lacisaponensis.

\section{Description of Nitrincola lacisaponensis sp. nov.}

Nitrincola lacisaponensis (la.ci.sa.po.nen'sis. L. n. lacus lake; L. n. sapo -onis soap; N.L. masc. adj. lacisaponensis pertaining to Soap Lake).

Cells are short, motile rods, occurring singly or in pairs $(1.3-1.5 \mu \mathrm{m}$ in length and $0.5 \mu \mathrm{m}$ in width). When grown on alkaline nutrient agar, colonies are $3-4 \mathrm{~mm}$ in diameter, whitish-beige-coloured, entire, smooth and convex. Obligate alkaliphile. Oxidase and catalase are produced. Lysine decarboxylase, ornithine decarboxylase and arginine dihydrolase are not produced; nor are $\mathrm{H}_{2} \mathrm{~S}$, acetoin or indole. Urea, gelatin, DNA and starch are not hydrolysed. No visible or fluorescent pigments are formed during incubation on solid King's media B or A, respectively. Strain $4 \mathrm{CA}^{\mathrm{T}}$ can grow with $\mathrm{O}_{2}$ or $\mathrm{NO}_{2}^{-}$as electron acceptors in the presence of acetate, but not with $\mathrm{NO}_{3}^{-}, \mathrm{SO}_{4}^{2-}, \mathrm{SO}_{3}^{2-}$ or $\mathrm{Se}_{4}^{2-}$. Carbon-source utilization is restricted to a limited range of organic acids, including DL-lactate, acetate, pyruvate, malate, fumarate and succinate. Glycine, L-alanine, L-arginine, L-asparagine, L-aspartic acid, Lglutamic acid, L-glutamine, L-isoleucine, L-leucine, L-ornithine, L-phenylalanine, sarcosine, L-threonine, Lserine, L-tryptophan, L-methionine, mannitol, D-mannose, D-arabinose, sucrose, D-xylose, glucose, D-galactose, cellobiose, D-fructose, D-ribose, ethanol, adonitol, glycerol, dulcitol, sorbitol, propanol, lactose, glucuronate, saccharate, hippurate, vanillate, coumarate and benzoate are not utilized. Cells are resistant to erythromycin, bacitracin, novobiocin, polymyxin $\mathrm{B}$, neomycin, gentamicin, streptomycin, carbenicillin, rifampicin and tetracycline, and are susceptible to nalidixic acid, chloramphenicol, ampicillin and penicillin. In minimal medium (SBM) containing acetate, the conditions for growth are $\mathrm{pH} 7 \cdot 5-11 \cdot 0$ and up to $1.3 \mathrm{M} \mathrm{NaCl}$. Optimum growth occurs at $\mathrm{pH} 9 \cdot 0$ and at $0 \cdot 8 \mathrm{M} \mathrm{NaCl}$. The DNA G $+\mathrm{C}$ content is $47 \cdot 4 \mathrm{~mol} \%\left(T_{\mathrm{m}}\right)$.

Isolated from decayed wood collected at Soap Lake, a saline, alkaline environment. The type strain is $4 \mathrm{CA}^{\mathrm{T}}$ (=ATCC BAA $-920^{\mathrm{T}}=$ DSM $16316^{\mathrm{T}}$ ).

\section{Acknowledgements}

The authors acknowledge Dr Randy Tindall, University of MissouriColumbia Electron Microscopy Core. We also acknowledge Catherine Albaugh and the staff of WSU Electron Microscopy Center for the flagellum TEM image. We are also grateful to Shitalben
Radheshyambhai Patel, University of Missouri-Rolla, and Amber Stratman, Truman State University, for help with the phenotypic characterization of the isolate. This work was supported by the Microbial Observatories Program of the United States National Science Foundation (MCB-0132158).

\section{References}

Anderson, G. C. (1958). Seasonal characteristics of two saline lakes in Washington. Limnol Oceanogr 3, 51-68.

Cutter, L., Sowers, K. R. \& May, H. D. (1998). Microbial dechlorination of 2,3,5,6-tetrachlorobiphenyl under anaerobic conditions in the absence of soil or sediment. Appl Environ Microbiol 64, 2966-2969.

Dabboussi, F., Hamze, M., Singer, E., Geoffroy, V., Meyer, J.-M. \& Izard, D. (2002). Pseudomonas mosselii sp. nov., a novel species isolated from clinical specimens. Int J Syst Evol Microbiol 52, 363-376.

Duckworth, A. W., Grant, W. D., Jones, B. E. \& van Steenbergen, R. (1996). Phylogenetic diversity of soda lake alkaliphiles. FEMS Microbiol Ecol 19, 181-191.

Fuse, H., Takimura, O., Murakami, K., Yamaoka, Y. \& Omori, T. (2000). Utilization of dimethyl sulfide as a sulfur source with the aid of light by Marinobacterium sp. strain DMS-S1. Appl Environ Microbiol 66, 5527-5532.

González, J. M. \& Whitman, W. B. (2002). Oceanospirillum and related genera. In The Prokaryotes: an Evolving Electronic Resource for the Microbiological Community, 3rd edn. Edited by M. Dworkin, release 3.9, 1 April 2002. New York: Springer. http://link.springer-ny. com/link/service/books/10125/

González, J. M., Mayer, F., Moran, M. A., Hodson, R. E. \& Whitman, W. B. (1997). Microbulbifer hydrolyticus gen. nov., sp. nov., and Marinobacterium georgiense gen. nov., sp. nov., two marine bacteria from a lignin-rich pulp mill waste enrichment community. Int J Syst Bacteriol 47, 369-376.

Hedlund, B. P., Geiselbrecht, A. D., Bair, T. J. \& Staley, J. T. (1999). Polycyclic aromatic hydrocarbon degradation by a new marine bacterium, Neptunomonas naphthovorans gen. nov., sp. nov. Appl Environ Microbiol 65, 251-259.

Horikoshi, K. (1998). Alkaliphiles. In Extremophiles: Microbial Life in Extreme Environments, pp. 155-179. Edited by K. Horikoshi \& W. D. Grant. New York: Wiley.

Hylemon, P. B., Wells, J. S., Jr, Krieg, N. R. \& Jannasch, H. W. (1973). The genus Spirillum: a taxonomic study. Int J Syst Bacteriol 23, 340-380.

Ivey, D. M., Ito, M., Gilmour, R., Zemsky, J., Guffanti, A. A., Sturr, M. G., Hicks, D. B. \& Krulwich, T. (1998). Alkaliphile bioenergetics. In Extremophiles: Microbial Life in Extreme Environments, pp. 181210. Edited by K. Horikoshi \& W. D. Grant. New York: Wiley.

Jones, B. E., Grant, W. D., Collins, N. C. \& Mwatha, W. E. (1994). Alkaliphiles: diversity and identification. In Bacterial Diversity and Systematics, pp. 195-229. Edited by F. G. Priest, A. RamosCormenzana \& B. J. Tindall. New York: Plenum.

Jones, B. E., Grant, W. D., Duckworth, A. W. \& Owenson, G. G. (1998). Microbial diversity of soda lakes. Extremophiles 2, 191-200.

King, E. O., Ward, M. K. \& Raney, D. E. (1954). Two simple media for the demonstration of pyocyanin and fluorescein. J Lab Clin Med 44, 301-307.

Ma, Y., Zhang, W., Xue, Y., Zhou, P., Ventosa, A. \& Grant, W. D. (2004). Bacterial diversity of the Inner Mongolian Baer Soda Lake as revealed by $16 \mathrm{~S}$ rRNA gene sequence analyses. Extremophiles 8, $45-51$. 
Marmur, J. (1961). A procedure for the isolation of deoxyribonucleic acid from microorganisms. J Mol Biol 3, 208-218.

Marmur, J. \& Doty, P. (1962). Determination of the base composition of deoxyribonucleic acid from its thermal denaturation temperature. J Mol Biol 5, 109-118.

Moore, E. R. B., Mau, M., Arnscheidt, A., Böttger, E. C., Hutson, R. A., Collins, M. D., Van De Peer, Y., De Wachter, R. \& Timmis, K. N. (1996). The determination and comparison of the 16S rRNA gene sequence of species of the genus Pseudomonas (sensu stricto) and estimation of the natural intrageneric relationships. Syst Appl Microbiol 19, 478-492.

Mormile, M. R., Romine, M. F., Garcia, M. T., Ventosa, A., Bailey, T. J. \& Peyton, B. M. (1999). Halomonas campisalis sp. nov., a denitrifying, moderately haloalkaliphilic bacterium. Syst Appl Microbiol 22, 551-558.

Owen, R. J. \& Hill, L. R. (1979). The estimation of base compositions, base pairing and genome size of bacterial deoxyribonucleic acids. In Identification Methods for Microbiologists, 2nd edn, pp. 217-296. Edited by F. A. Skinner \& D. W. Lovelock. London: Academic Press. Palleroni, N. J. (1984). Genus I. Pseudomonas Migula 1984, $237^{\mathrm{AL}}$ (Nom. cons. Opin. 5, Jud. Comm. 1952, 237). In Bergey's Manual of Systematic Bacteriology, vol. 1, pp. 141-199. Edited by N. R. Krieg \& J. G. Holt. Baltimore: Williams \& Wilkins.

Pot, B., Gillis, M., Hoste, B., Van De Velde, A., Bekaert, F., Kersters, K. \& De Ley, J. (1989). Intra- and intergeneric relationships of the genus Oceanospirillum. Int J Syst Bacteriol 39, 23-34.

Pot, B., Gillis, M. \& De Ley, J. (1992). The genus Oceanospirillum. In The Prokaryotes: a Handbook on the Biology of Bacteria: Ecophysiology, Isolation, Identification, Applications, 2nd edn, vol. 4, pp. 3230-3236. Edited by A. Balows, H. G. Trüper, M. Dworkin, W. Harder \& K.-H. Schleifer. New York: Springer.

Rees, H. C., Grant, W. D., Jones, B. E. \& Heaphy, S. (2004). Diversity of Kenyan soda lake alkaliphiles assessed by molecular methods. Extremophiles 8, 63-71.

Relman, D. A., Schmidt, T. M., MacDermott, R. P. \& Falkow, S. (1992). Identification of the uncultured bacillus of Whipple's disease. $N$ Engl J Med 327, 293-301.
Sakane, T. \& Yokota, A. (1994). Chemotaxonomic investigation of heterotrophic, aerobic and microaerophilic spirilla, the genera Aquaspirillum, Magnetospirillum and Oceanospirillum. Syst Appl Microbiol 17, 128-134.

Satomi, M., Kimura, B., Hamada, T., Harayama, S. \& Fujii, T. (2002). Phylogenetic study of the genus Oceanospirillum based on 16S rRNA and gyrB genes: emended description of the genus Oceanospirillum, description of Pseudospirillum gen. nov., Oceanobacter gen. nov. and Terasakiella gen. nov. and transfer of Oceanospirillum jannaschii and Pseudomonas stanieri to Marinobacterium as Marinobacterium jannaschii comb. nov. and Marinobacterium stanieri comb. nov. Int J Syst Evol Microbiol 52, 739-747.

Shukla, S. K., Vevea, D. N., Frank, D. N., Pace, N. R. \& Reed, K. D. (2001). Isolation and characterization of a black-pigmented Corynebacterium sp. from a woman with spontaneous abortion. J Clin Microbiol 39, 1109-1113.

Smibert, R. M. \& Krieg, N. R. (1994). Phenotypic characterization. In Methods for General and Molecular Bacteriology, pp. 607-655. Edited by P. Gerhardt, R. G. E. Murray, W. A. Wood \& N. R. Krieg. Washington, DC: American Society for Microbiology.

Stanier, R. Y., Palleroni, N. J. \& Doudoroff, M. (1966). The aerobic pseudomonads: a taxonomic study. J Gen Microbiol 43, 159-271.

Swofford, D. L. (2003). PAUP*: Phylogenetic analysis using parsimony (*and other methods), version 4 . Sunderland, MA: Sinauer Associates.

Thompson, J. D., Higgins, D. G. \& Gibson, T. J. (1994). CLUSTAL W: improving the sensitivity of progressive multiple sequence alignment through sequence weighting, position-specific gap penalties and weight matrix choice. Nucleic Acids Res 22, 4673-4680.

Walker, K. F. (1974). The stability of meromictic lakes in central Washington. Limnol Oceanogr 19, 209-222.

Weisburg, W. G., Barns, S. M., Pelletier, D. A. \& Lane, D. J. (1991). 16 S ribosomal DNA amplification for phylogenetic study. J Bacteriol 173, 697-703.

Zavarzin, G. A., Zhilina, T. N. \& Kevbrin, V. V. (1999). The alkaliphilic microbial community and its functional diversity. Microbiology (English translation of Mikrobiologiia) 68, 503-521. 